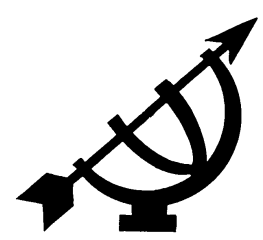

\title{
The voices of victims and witnesses of school bullying
}

Corene de Wet

Department of Comparative Education and Education Management

School of Education

University of the Free State

BLOEMFONTEIN

E-mail: dewetnc.hum@mail.uovs.ac.za

Abstract

The voices of victims and witnesses of school bullying

There has never been a stronger demand from the South African public to reduce school violence than at present. The demand for safe schools cannot be achieved unless the issue of bullying is adequately addressed. However, it appears from newspaper reports that some of the role players are not willing to listen to the victims of bullying. The aim of this article is to give a voice to some of the victims, as well as those witnessing school bullying. This article reports on findings from an investigation of the experiences of a group of Free State learners who were witnesses and victims of bullying. The research instrument was the Delaware Bullying Questionnaire. The first important conclusion from this study was that bullying was a serious problem in some Free State schools. Secondly, it was found that the respondents were more often the victims of male than of female bullies. Thirdly, the quantitative data indicated that the majority of victims were bullied by learners who were in the same grade as they were. The qualitative data, however, revealed that the bullying of Grade 8 learners by Grade 12 learners seems to be a fairly common occurrence. Finally, some comments and recommendations are made.

\section{Opsomming}

Die stemme van slagoffers en getuies van skoolbullebakkery

Die Suid-Afrikaanse gemeenskap is tans onverbiddelik in hulle eis dat geweld in skole hanteer word. Die daarstelling van veilige skole is 'n onbereikbare doel indien die kwessie van bullebakkery nie voldoende hanteer word nie. Dit blyk egter uit 
koerantberigte dat sommige rolspelers nie bereid is om na die slagoffers van bullebakkery te luister nie. Die doel van hierdie artikel is om 'n stem aan sommige van die slagoffers en getuies van skoolbullebakkery te gee. Die artikel lewer verslag van 'n groep Vrystaatse leerders se ervarings van en waarnemings van bullebakkery. Die navorsingsinstrument was die Delaware Bullebakkery-vraelys. Die eerste belangrike konklusie van hierdie studie is dat bullebakkery 'n ernstige probleem in sommige Vrystaatse skole is. Daar is tweedens bevind dat die respondente meer dikwels die slagoffers van manlike as vroulike bullebakke was. Die kwantitatiewe data het derdens aangedui dat die meerderheid van die slagoffers deur leerders wat in dieselfde graad as hulle was, geviktimiseer is. Die kwalitatiewe data het egter aangedui dat die viktimisering van graad 8-leerders deur graad 12-leerders 'n redelik algemene verskynsel is. Laastens word enkele opmerkings en aanbevelings gemaak.

\section{Introduction}

There has never been a stronger demand from the South African public to reduce school violence than at present (Beaver, 2005:9; Blaine, 2005:4; Naran, 2005:4; Smit, 2005:5). Ma, Stewin and Mah (2003:264) assert that the goal of creating safe schools cannot be achieved unless the issue of bullying is adequately addressed. From a reading of newspaper reports that have been published on this topic in 2005, it seems as if bullying is rife in some South African schools. According to the Saturday Star (Anon., 2005:3) a 16 year old girl was "allegedly forced to drink a bottle of Jik by a trio of school bullies". She died. The girl's father (as quoted by Serrao \& Russouw, 2005:3) alleges that the girl's cries for help were dismissed by members of staff as those of a "drama queen". In another article Du Toit (2005:1) gives a sympathetic account of a 16 year old boy's fear of attending school after he had been verbally and physically abused by his fellow classmates. His mother's attempt to lay criminal charges against the alleged perpetrators was unsuccessful - a police officer dismissed the charges as "childish".

The foregoing reveals a serious discrepancy: the South African public is demanding a reduction in school violence, yet some of the role players are not listening to the cries for help by the victims of bullying. When adults accept bullying as an unfortunate stage that some children go through, the potential for bullying to escalate into more violent acts, as have happened in the aforementioned incidents, increases. Through their passivity, adults are implying that bullying is acceptable behaviour. The aim of this article is to give a 
voice to some of the victims, as well as those witnessing school bullying. Against the background of the preceding statement of the problem and a short literature review, this article will report on a study on bullying in Free State secondary schools. The article will attempt to answer the following questions:

- What are Free State learners' experiences of bullying?

- Who are the bullies?

- In whom did the victims confide after being bullied?

\section{Literature review}

\subsection{A definition of bullying}

Olweus (2000a:10), one of the world's leading experts on bullying, defines school bullying in the following general way: "... a student is being bullied or victimised when he or she is exposed, repeatedly and over time, to negative action on the part of one or more students". Olweus (2000a:10) explains the term "negative action" as follows: "... a negative action is when someone intentionally inflicts, or attempts to inflict injury or discomfort upon another". Negative actions can be carried out by physical contact, by words, or in other ways, such as making faces or mean gestures and intentional exclusion from a group. In Olweus's (2000a:11) definition, bullying is characterised by the following three criteria: It is aggressive behaviour or intentional "harm doing" which is carried out "repeatedly and over time" in an interpersonal relationship, characterised by an imbalance of power. According to Olweus (2000a:11) one might add that bullying behaviour often occurs without apparent provocation.

Bullying can be either direct (e.g., verbal and physical aggression) or indirect (e.g., threats, insults, name calling, spreading rumours, writing hurtful graffiti, or encouraging others not to play with a particular child). Indirect bullying involves purposeful actions that lead to social exclusion or damage to a child's status or reputation in an attempt to get others not to socialise with the victim (De Wet, 2005:83; Smokowski \& Kopasz, 2005:102). Whitted and Dupper (2005:168) delineate two other types of bullying - racial bullying and sexual bullying. Racial bullying consists of making racial slurs, writing graffiti, mocking the victim's culture or making offensive gestures. Sexual bullying includes passing inappropriate notes, jokes, pictures, taunts, or starting rumours of a sexual nature. Sexual bullying may also involve physically intrusive behaviour, such 
as the grabbing of private parts, or forcing someone to engage in sexual behaviours. Cognisance should also be taken of what Belsey (2004, quoted in Keith \& Martin, 2005:224) calls cyber-bullying.

In the next section attention will be given to the consequences of direct and/or indirect verbal, physical, sexual and/or racial negative actions carried out repeatedly and over time on the victims, bystanders, aggressors (bullies), parents, educational authorities and the community at large.

\subsection{The consequences of bullying}

Bullying others and being victimised have negative long- and shortterm consequences on the general health and well-being of the learners involved. A poor mental and psychical condition might be linked to experiences of victimisation at school. Bullying others is an indicator of maladjustment and therefore, it might also be related to poor health, because of the stress attached to it (Baldry, 2004:344). Research findings (Baldry, 2004:344) indicate that regardless of the type of victimisation to which victimised children were exposed, they reported relatively high levels of internalised problems. Victims of bullying often suffer from mental health conditions, with high levels of depression and suicidal ideation. With reference to physical health, Baldry (2004:344) found that victims of persistent bullying often develop a series of somatic complaints, including headaches and stomach aches. Poor mental and physical health prevents learners from feeling happy at school and achieving good or satisfactory goals. Within the school environment, the victim may thus have impaired concentration, decreased academic performance, truancy from school (to prevent bullying from occurring), or absence from special school activities or certain classes. They may fear rejection, being excluded or ignored, may feel betrayed, or fear being ridiculed in class by the spread of nasty rumours. Victims of bullying may also feel lonely and isolated from their friends and classmates. Victims of bullying often bring home their frustrations in school and lash out at their parents who are more than likely unaware of their children's victimisation at school. As a result, family relationships are likely to deteriorate (Whitted \& Dupper, 2005:167; Selekman \& Vessey, 2004:247; Ma et al., 2003:251).

Dake et al. (2003:175) have found that there is a strong relationship between bullying and behavioural misconduct. When comparing bullies to learners not involved in bullying behaviour, bullies are significantly more likely to become involved in self-destructive behaviours, such as alcohol and tobacco abuse and fighting. 
Significant relationships also exist between bullying others and weapon carrying, cheating in tests, stealing, truancy, vandalism and having problems with the police.

The repercussions of bullying are rarely limited to the victims and bullies alone. This may be ascribed to the fact that bystanders are present in $85 \%$ of bullying episodes. Bullying has been shown to be a group process in which $63 \%$ of children play a "participant role" such as bullying, victim, defender, bully's assistant, or reinforcer (Eslea et al., 2003:72). Learners in schools with serious bullying problems feel less safe and less satisfied with their schools. Learners in schools where bullying problems are ignored and aggressive behaviour is not addressed, are likely to become more aggressive and less tolerant as well (Whitted \& Dupper, 2005:167; Eslea et al., 2003:72).

It should furthermore be noted that schools in South Africa have a legal duty

... to provide learners with a safe and secure environment, and to protect them from deviant behaviour that affects their wellbeing and infringes on their basic rights to security, human dignity, privacy and education (Squelch, 2000:53).

A school's inability to honour the aforesaid obligations may have serious consequences. In 2005 the Department of Education of Gauteng Province was, for example, named as the respondent in an average of 12 civil cases per month that centred on injuries inflicted by learners on other learners on school premises. According to Makgalemele (2005:1) these cases are in line with Section 60 of the South African Education Law and Policy Handbook which says that the state is liable for damage or loss due to any act of omission in connection with an educational activity conducted by a public school, and for which a public school would have been liable, but for the provision of this section (cf. Education Law Newsletter [2001:1-4] and Crawthon [1999:1-2] for discussions of similar civil suit cases lodged by parents against educational authorities in the USA and New Zealand).

Bullying thus not only infringes on the child's right to receive education in a safe and secure school environment, but may also have dire consequences for a child's academic, relational, emotional and behavioural development. 


\subsection{Research on the prevalence of bullying}

Learners often hear their parents and educators utter the following remarks:

Being bullied is just part of growing up. You need to stand up for yourself. Boys will be boys. You need to toughen up. Don't be so sensitive. They tease you because they like you. They're just jealous (Will \& Neufeld, 2002:51).

These remarks, implying that bullying is part of the developmental process, are uttered by adults whom learners love and respect. This results in victims not being willing to tell their parents and educators that they are being bullied. Some victims fear revenge from the bully or even classmates, who will regard the disclosure as telling tales. If the bullying is severe or continues over a long period of time, the victims fear that it will upset their parents, especially when they think that their parents cannot change the situation. Children are sometimes not willing to admit that they have given expensive items or money to bullies. Parents set not only academic expectations, but also social expectations to their children. Consequently, victimised children, who feel rejected and unpopular, are not willing to admit that they are being bullied. In their endeavour towards greater independence, adolescents often feel that they should be able to cope with the problem themselves. The child-parent/learnereducator relationship during adolescence is also often tense, and communication channels are not always what they should be (Besag, 1991:103-104). For these reasons, many parents and educators are unaware of the levels of bullying to which their children and/or learners are exposed.

Nonetheless, from the following research results it is apparent that bullying is a relatively common phenomenon. Research on the prevalence of bullying has occurred in, among others, Norway, Finland, Britain, Australia, the USA and South Africa. The prevalence of victimisation in elementary schools (Grades 1-5) varies from $11,3 \%$ in a sample of 5813 learners in Finland, to 49,8\% in a nationwide sample $(n=7290)$ of learners in Ireland. Prevalence ranges from $4,7 \%$ in a sample of 189 Finnish eighth graders, to $27 \%$ in a sample of 6758 middle school learners in the United Kingdom. A USA study found that between $9 \%$ and $11 \%$ of middle school learners were bullied "sometimes" or more frequently. In secondary schools (Grades 9-12) the prevalence of bullying ranged from 4,2\% in a large sample of British learners, to $25 \%$ in a small sample of Australian learners (Dake et al., 2003:173-174). On the basis of a 
large-scale survey, Olweus (2000b:32) estimated that $15 \%$ of the learners in primary and lower secondary schools (roughly corresponding to ages 7 through to 16) in Norway were involved in bully/victim problems with some regularity - either as bullies or victims. Neser et al. (2003:153) found that $60,9 \%$ of the 207 participants in a research project in Gauteng, South Africa, indicated that they were bullied during the 2002 school year. According to the First South African national youth risk behaviour survey (Department of Health, 2002:145) 49,3\% of secondary school learners in the Free State of South Africa reported that they had been bullied in the month preceding the survey.

A 2003 survey on cyber-bullying in the USA found that $57 \%$ of the learner participants said that someone had said hurtful or nasty things to them online, with $13 \%$ saying it happened "quite often" (Keith \& Martin, 2005:225). A study in 2004 by the Australian Psychological Society of 258 Melbourne and Sydney learners in Grades 7 to 12 found that $10 \%$ had received threatening messages on their cellphones and $29 \%$ had messages from people with whom they did not want contact (Youth Studies Australia, 2005a:5).

It is apparent from the aforementioned research findings, that bullying has been and still is a considerable problem nationally and internationally and it affects a large number of learners. Cognisance should, nonetheless, be taken of Olweus's (2000b:33) comment that differences in levels of bullying should be considered with caution, since learners' responses may be affected by such factors as learners' language proficiency, familiarity with the concept of bullying in the relevant culture, the degree of public attention to the problem, as well as the differentiating age ranges of the participants in the different surveys.

\section{Empirical investigation}

\subsection{Research instrument}

An investigation was conducted during 2004 to determine the experiences of a group of Free State secondary school learners who were victims and witnesses of bullying. The research instrument was the Delaware Bullying Questionnaire (State of Delaware, s.a.). Section $A$ of the structured questionnaire provides biographical details of the respondents. In Section B, questions are asked about the respondents as possible victims (Table 2) of bullying. In Section $\mathrm{C}$ an attempt is made to obtain information on who the persons were by whom, if applicable, the respondents were bullied (Tables 3 and 
4). An attempt was also made to find out in whom victims of bullying confided (Table 5). In Section D an open-ended question attempts to obtain qualitative data on respondents' experiences and/or observations of bullying. This question reads as follows: "If you want to, describe a specific incident of bullying at your school which you witnessed or experienced (without using names) which you believe others should know about, and about which something should have been done." This questionnaire was adapted for the South African situation (compare questions on the use of taxis as means of transport).

\subsection{The test sample}

The universum consisted of learners from secondary schools in the Free State. A random test sample of 60 of the 335 secondary and combined schools in the Free State was drawn from an address list supplied by the Free State Department of Education. Six hundred questionnaires, 10 per school, were sent by post. Of the returned questionnaires, $339(56,5 \%)$ were suitable for processing. The average age of the respondents, $160(47,2 \%)$ of whom were boys and $179(52,8 \%)$ girls, was 16 years and 3 months. Table 1 summarises the grade and gender distribution of the respondents:

Table 1: Grade and gender variables of the respondents

\begin{tabular}{|r|c|c|c|c|}
\hline Grade & \multicolumn{2}{|c|}{ Boys } & \multicolumn{2}{c|}{ Girls } \\
\hline & $\mathbf{n}$ & $\%$ & $\mathbf{n}$ & $\%$ \\
\hline 9 & 11 & 6,88 & 14 & 7,82 \\
\hline 10 & 29 & 18,12 & 19 & 10,62 \\
\hline 11 & 43 & 26,88 & 30 & 16,76 \\
\hline 12 & 54 & 14,37 & 59 & 32,96 \\
\hline Total & 160 & 100,00 & 179 & 100,00 \\
\hline
\end{tabular}




\subsection{Processing of data}

In Section B of the questionnaire, respondents had to make use of the following response: 1 = daily; 2 = once or twice a week; $3=$ once or twice a month; $4=$ once or twice a year; $5=$ never. The respondents' answers were then determined by mathematical calculations. Furthermore, the average gradation of each item was determined and the rank order established. The respondents' responses to questions on who bullied them, if applicable (Tables 3 and 4), as well as their responses with regard to the persons in whom they confided after being victimised (Table 5), were determined by means of mathematical calculations. A number of respondents, $79(36,87 \%)$ girls and $66(41,25 \%)$ boys, met the request to describe a specific incident of bullying. Due to the limited space available, only a few of their answers will be used to elucidate the quantitative data.

\subsection{Results}

Table 2 summarises the respondents' experiences as victims of various types of bullying in sequence of the most common to the least common type of bullying to which they were exposed.

Respondents are mostly exposed to direct (Table 2, item 2) and the second most to indirect (Table 2, item 4) verbal harassment. Only $29,20 \%$ and $32,15 \%$ of the respondents were never exposed to direct and indirect verbal harassment, respectively. A Grade 12 girl gave the following description of verbal bullying at her school:

In lower grades you get that the children write graffiti on the walls of the bathrooms of names of other children and call them names. They also make use of cell-phones and send nasty messages to the targets. 
Table 2: The respondents' exposure to different types of bullying

\begin{tabular}{|c|c|c|c|c|c|c|c|c|c|c|c|c|c|}
\hline \multirow[t]{2}{*}{ Item } & \multirow[t]{2}{*}{ RO } & \multirow[t]{2}{*}{ MR } & \multirow[t]{2}{*}{ Questions } & \multicolumn{2}{|c|}{1} & \multicolumn{2}{|c|}{2} & \multicolumn{2}{|c|}{3} & \multicolumn{2}{|c|}{4} & \multicolumn{2}{|c|}{5} \\
\hline & & & & $\mathbf{n}$ & $\%$ & $\mathbf{n}$ & $\%$ & $\mathbf{n}$ & $\%$ & $\mathbf{n}$ & $\%$ & $\mathbf{n}$ & $\%$ \\
\hline 2 & 1 & 3,54 & $\begin{array}{l}\text { How often do other learners bully you by } \\
\text { saying mean things to you (things that } \\
\text { hurt your feelings)? }\end{array}$ & 25 & 7,38 & 49 & 14,46 & 83 & 24,48 & 83 & 24,48 & 99 & 29,20 \\
\hline 4 & 2 & 3,72 & $\begin{array}{l}\text { How often do other students bully you by } \\
\text { spreading mean rumours about you? }\end{array}$ & 26 & 7,67 & 35 & 10,33 & 56 & 16,52 & 113 & 33,33 & 109 & 32,15 \\
\hline 1 & 3 & 4,20 & $\begin{array}{l}\text { How often do other learners bully you by } \\
\text { laying their hands on you (hitting, kicking, } \\
\text { or pushing or hurting your body) in school } \\
\text { or on the school bus/taxi? }\end{array}$ & 12 & 3,54 & 26 & 7,67 & 24 & 7,08 & 48 & 14,16 & 230 & 67,55 \\
\hline 3 & 4 & 4,27 & $\begin{array}{l}\text { How often do other learners bully you by } \\
\text { making sexual comments that bother } \\
\text { you? For instance, commenting on your } \\
\text { body, calling you gay, talking to you } \\
\text { about sex, etc. }\end{array}$ & 16 & 4,71 & 26 & 7,67 & 25 & 7,38 & 56 & 16,52 & 216 & 63,72 \\
\hline 5 & 5 & 4,25 & $\begin{array}{l}\text { How often do other learners bully you by } \\
\text { leaving you out of their activities to hurt } \\
\text { your feelings at school or on the school } \\
\text { bus/taxi? }\end{array}$ & 14 & 4,13 & 16 & 4,72 & 36 & 10,62 & 78 & 23,01 & 195 & 57,52 \\
\hline 6 & 6 & 4,79 & $\begin{array}{l}\text { How often have you been bullied into } \\
\text { giving up lunch/pocket money, food, } \\
\text { drinks or snacks? }\end{array}$ & 5 & 1,47 & 5 & 1,47 & 10 & 2,95 & 15 & 4,42 & 304 & $89, .67$ \\
\hline Av. & & 4,13 & & & & & & & & & & & \\
\hline
\end{tabular}

1. Daily.

$\mathrm{RO}=$ Rank order
2. Once or twice a week. 3. Once or twice a month. $\mathrm{MR}=$ Mean rating
4. Once or twice a year. 5. Never. 
Direct, physical aggression is the third most common form of bullying to which the respondents are exposed (Table 2, item 1). From the respondents' descriptions of the incidence of physical aggression, it is apparent that physical aggression may take many forms: some victims were forced to do what they perceived to be demeaning physical labour, e.g. washing the bullies' shirts and/or socks, cleaning their shoes, and/or carrying the bullies' books to and from school. Victims were sometimes forced to dive into holes and/or lie on the ground. Some respondents described how they, or fellow learners were severely kicked or beaten, or even forced to put sand in their mouths. Some of these acts were performed under the pretext of the initiation of new learners at the beginning of the academic year.

Sometimes the fear evoked by the physical strength of a bully was enough to force the victim to comply with the bully's demands:

... the Grade 8 boy started trembling and you could see that he wanted to cry. Nobody helped him because the Grade 12 boy was very strong. So the Grade 8 boy told the Grade 12 boy that he will give him money the following day.

Although sexual bullying is only fourth in a sequence of six types of bullying among the respondents, $42(12,38 \%)$ of the respondents were sexually harassed either daily, or at least once a week by other learners. From the following description by an 18 year old girl, it is obvious that it is a serious problem in some schools:

At our school yard sometimes when girls pass the boys' toilets you will hear boys saying silly things to them, touching their private parts and trying to throw them in their toilets. And there is no doubt that if they can manage to get girls in there it will be trouble.

Several respondents wrote that learners who did not conform to traditional gender stereotypes were humiliated by means of derogatory name-calling.

Tables 3 and 4 will summarise the respondents' answers on the identity of the bullies. The qualitative data following these tables will also refer, among other things, to incidents of physical bullying. 
Table 3: The persons who bullied the respondents

\begin{tabular}{|l|r|r|r|r|r|}
\hline & \multicolumn{2}{|l|}{$\begin{array}{l}\text { Verbal } \\
\text { bullying* }\end{array}$} & \multicolumn{2}{l|}{$\begin{array}{l}\text { Physical } \\
\text { bullying** }\end{array}$} \\
\hline & \multicolumn{1}{|l|}{$\mathbf{n}^{\star * *}$} & $\%^{* \star \star *}$ & $\mathbf{n}$ & \multicolumn{2}{l|}{$\%$} \\
\hline Both boy(s) and girl(s) & 65 & 19,17 & 5 & 1,47 \\
\hline Several boys & 60 & 17,70 & 24 & 7,08 \\
\hline A boy & 25 & 7,37 & 32 & 9,44 \\
\hline Several girls & 43 & 12,68 & 12 & 3,54 \\
\hline A girl & 33 & 9,73 & 9 & 2,65 \\
\hline $\begin{array}{l}\text { An adult who works for the } \\
\text { school }\end{array}$ & 8 & 2,36 & 3 & 0,89 \\
\hline Nobody & 123 & 36,28 & 254 & 74,93 \\
\hline Total & 357 & & 339 & 100,00 \\
\hline
\end{tabular}

* Who has bullied you by saying mean things to you, teasing you, calling you names, spreading rumours about you or trying to be mean on the bus/taxi?

** Who has bullied you by laying hands on you (hitting, kicking, pushing or hurting your body) at school or on the bus/taxi?

*** Some respondents indicated more than one category of bullies.

**** Percentage of respondents.

From Table 3 it is apparent that boys, more often than girls, are guilty of both physical and verbal bullying. Some of the boys described in the open-ended question how they were kicked or beaten by other boys. A Grade 11 boy gave the following account of his harrowing experiences:

I was in Grade 9 and Grade 12s from the hostel commanded me to fetch something for them during a meal. I refused. After the meal the Grade 12s sent one boy from their group to beat me up. Their hero came and he assaulted me until I fell to the ground. They came to stop him, but he continued and kicked me in the face. I was too scared to tell, because they would hit me again. In Grade 10 my roommate was in Grade 12 and he stole from me. When I confronted him, he kicked me in the face 
until I bled. I could not tell on him, because his family was known for assaulting people.

It seems that boys are not only hitting other boys, but also members of the opposite gender. A Grade 11 girl wrote that she saw how a boy "kicked and pushed a girl after school hours". Several onlookers seemed to find the incident funny ("others said nothing ... they only laughed"). Another respondent describes how a boy used his fists "to hit an innocent girl". From the following short description, it can be deduced that some victims are bullied by members of both sexes: "The whole class turned on a girl, and actually physically assaulted her."

Table 4: Grade level of the learners who bullied the respondents

\begin{tabular}{|l|r|r|}
\hline & \multicolumn{1}{c|}{$\mathbf{n}^{*}$} & \multicolumn{1}{c|}{ \%** $^{* *}$} \\
\hline $\begin{array}{l}\text { In my class } \\
\text { different class }\end{array}$ & 54 & 29,35 \\
\hline In a lower grade & 64 & 34,78 \\
\hline In a higher grade & 13 & 7,06 \\
\hline Total & 53 & 28,81 \\
\hline
\end{tabular}

* 155 of the 339 respondents indicated that they had not been bullied.

** Percentage of the respondents who indicated that they had been bullied $(n=184)$.

According to Table 4, of the respondents who were bullied $64,13 \%$ were victims of learners who were in the same grade as they. However, it became evident from the respondents' answers to the open-ended question, that the victimisation of Grade 8 learners by Grade 12 learners is widespread during the first few weeks of the new academic year. One of the respondents gave the following description:

Normally at my school during the first term, many newcomers are bullied. The seniors bully them by treating them very wicked. They normally force them to swim on the grass. People 
who treat other learners bad must know that it isn't right to harm other people's feelings because they don't show honour to them and newcomers will never enjoy the school (cf. the different tasks that the learners had to perform).

Table 5 gives a summary of the persons in whom the respondents confided that they were victims of bullying during the preceding 12 months.

Table 5: The persons in whom the respondents confided that they were victims of a bully(s) during the preceding 12 months

\begin{tabular}{|l|r|r|}
\hline & $\mathbf{n}^{*}$ & \%** $^{* *}$ \\
\hline My mother and/or father & 36 & 24,49 \\
\hline My brother and/or sister & 10 & 6,80 \\
\hline A teacher or adult at school & 15 & 10,20 \\
\hline Another child at school & 47 & 31,97 \\
\hline Nobody & 49 & 33,33 \\
\hline Total & $157^{*}$ & \\
\hline
\end{tabular}

* 192 of the 339 respondents indicated that they had not been bullied. Some respondents marked more than one category.

** Percentage of respondents who have been bullied (147).

A relatively large percentage of the respondents who were victims of bullying $(33,33 \%)$ did not tell anybody about their plight. The following two quotations give an insight into the respondents' selfincrimination, shame and guilt:

... when people are called names, it hurts too much (it is too embarrassing) to tell someone.

The first time I arrived at secondary school, I experienced someone bullying me. He did this just because I was stupid. I didn't want to protect myself because I was scared of him. He told me to give him some money. I didn't refuse. All I had was 50 cents. I told nobody about it, but instead I felt sorry about myself. There was no help. 
Not only the victims, but also the witnesses of bullying incidents are sometimes too afraid to take any action:

I told my friends at school, but didn't take any action because I

felt scared they would come after me.

A 16 year old respondent wrote how she was physically abused ("punished by hitting and pushing") during her Grade 8 year. Fear led her to tell her mother that she "was not going to school because it was boring. When I thought about the next day, I felt like running away." In retrospect she comments that "adults should know" about bullying. From the following, written by a 19 year old male respondent, it is apparent that it is important to break the code of silence:

I have been the victim of bullying by other boys and several girls - calling me names and telling me that I'm gay. I did nothing or tell anyone because I was very scared and confused, so after a few days I told my sister so I began to feel better again.

\subsection{Discussion and recommendations}

An important prerequisite for the successful implementation of a bullying prevention programme is an acknowledgement by role players that bullying is a problem that needs to be addressed (Olweus, Limber \& Mihalic, 1999:10). The use of a questionnaire, such as the Delaware Bullying Questionnaire (State of Delaware, s.a.), is a useful tool to create this awareness. The qualitative and quantitative data have shown that the majority of the respondents realise that bullying is a pervasive and serious problem in some Free State schools. Only $29,20 \%$ and $32,15 \%$ of the respondents indicated that they had never been the victims of direct and indirect verbal bullying respectively (Table 2). The gravity of the problem in some Free State schools is underlined by the respondents' descriptions of incidents of verbal, physical, sexual, as well as cyber-bullying.

The finding that a relatively large number of respondents were subjected to comments and/or gestures with a sexual meaning (cf. Table 2, item 3, as well as the references made by respondents to the verbal abuse directed at gay, or allegedly gay persons, and the description of the boys making sexual gestures and comments at girls passing their toilets) is in line with findings by Collins, McAleavy and Adamson (2004:68), namely that rude name-calling and comments, as well as gestures with a sexual meaning, has become an established method of intimidation and harassment. According to 
Douglas et al. (1998, quoted in Collins et al., 2004:68) homophobicrelated verbal abuse may not necessarily be targeted at young people who are known to be gay, but is used as a term of abuse towards individuals who may not be perceived as conforming to traditional gender stereotypes.

A finding of this study, namely that the respondents were more often the victims of male than female bullies (Table 3 ) is consistent with findings by Baldry $(2004: 344,352)$. However, with regard to cyberbullying, it was found by Keith and Martin (2005:225) that females inflict virtual abuse more often than males through instant messages, online conversations, and e-mails. Keith and Martin (2005:225) warn that with no boundaries or tangible consequences, children are using technology to vent frustrations in ways that can become very destructive. It is therefore important that educators and parents guide children to use technology in ways that promote respect, understanding and responsibility. Although the current research project has not addressed issues relating to cyber-bullying (cf. Table 2) it is apparent from the qualitative data ("They ... make use of cell-phones and send nasty messages to the targets") and a newspaper article (De Vries, 2002:9) that cyber-bullying is not an unknown phenomenon in South Africa. More and more learners in South Africa are gaining access to the cyber world. It is therefore necessary for researchers to address cyber-bullying in the South African context.

Data in Table 5 are an affirmation of research findings by Glover et al. (2000:150), namely that when victims of bullying decide to tell somebody of their ordeals, the best friend is the most common source of help in school, with a parent the most significant adult figure. In the light of the aforementioned findings, it is feasible that learners should play an active role in combating bullying. The majority of learners might be opposed to bullying and wish to support the victims, but in school yard reality, they remain silent bystanders ("I told my friends at school, but didn't take any action because I felt scared they would come after me") whose apathy only serves to condone violence ("others said nothing ... they only laughed"). It is therefore important to empower learners to help victims and bullies in an assertive, yet non-aggressive manner.

It is disconcerting to note that only $10,20 \%$ of the respondents who were victims of bullying indicated that they told an educator(s) of their negative experience (Table 5). This is in line with the findings by Rigby and Bagshaw (2003:543) that learners are unwilling to tell others, especially educators, that they are being victimised by 
bullies. It is thus crucial that educators should acknowledge that they may have a credibility problem with some children about how to deal satisfactorily with bully/victim problems. This may be remedied by demonstrating that educator intervention is much more likely to result in satisfactory outcomes for those learners they seek to help. It is also vital that educator intervention does not make matters worse. It is furthermore necessary to stress that the breaking down of communication blocks between educators and learners is a prerequisite for the success of any intervention strategy. According to Rodkin and Hodges (2003:396) educators are not powerless when it comes to bullying. Rather, they should be the leaders and diplomats of their classrooms. Their goal is not only to enforce rules, but also to resolve conflicts and promote healthy relationships. According to the aforementioned authors, educators are in a unique position to have a positive influence on childhood social dynamics.

The qualitative data suggests that some victims of bullying may have social skills problems. In support of previous research (Fox \& Boulton, 2005:324) the victims of bullying are perceived as displaying a behavioural vulnerability (e.g. "the Grade 8 boy started trembling and you could see that he wanted to cry" and "I was very scared and confused"), are non-assertive (e.g. "I did nothing or tell anybody"), reward and thus reinforcing the bully's behaviour (e.g. "He told me to give him the money. I didn't refuse" and "So the Grade 8 boy told the Grade 12 boy that he will give him money the following day"), and are withdrawn and solitary in their behaviour (e.g. "I did nothing or tell anybody"). Without implying that the victims of bullying are somehow to blame for their plight, it is recommended that children should be equipped with the social skills to resist bullying.

From the research data it is apparent that bullying is a problem in some Free State schools. It is thus necessary for the South African research community to research bullying in schools periodically and systematically. They should also, in partnership with other role players, initiate the development of an anti-bullying programme that can be adapted to the specific needs of individual schools. Several anti-bullying programmes, which may be used as exemplars, are available to make learners and educators aware of the nature and scope of the problems at their respective schools, as well as to empower them to identify and support victims and prevent bullying (see among others Treml, 2001:114; Guerin \& Hennessy, 1999:1-5). For the purpose of this article, reference will be made to only two programmes. While one is probably the most widely recognised anti- 
bullying programme worldwide, the other is still in its development stage in Australia. Olweus's (Olweus et al., 1999:9-10) whole-school programme is a comprehensive intervention programme. This programme targets all learners and relies on educators and other staff members, as well as on parents, for implementation. The programme prompts school personnel to create a school environment that is characterised by warmth and involvement, has firm limits on unacceptable behaviour, and allows adults to act as both authority figures and role models. The programme works with intervention at school-wide, classroom- and individual-level (Cipani, 2005:5; Smokowski \& Kopasz, 2005:106; Olweus, 2000b:39). The implementation of this programme has lead to a substantial reduction, by up to $50 \%$ or more, in the frequency with which learners reported being bullied and bullying others (Cipani, 2005:5; Olweus et al., 1999:10). An anti-bullying programme at De La Salle College, Caringbah, a Catholic secondary school for boys in the southern suburbs of Sydney, has reduced the number of detentions by $70 \%$. Suspensions have been reduced by half and truancies are down by $43 \%$ since the school began tackling problems of bullying. The school uses restorative justice. Bullies and victims sit in a circle and discuss their feelings to "heal" both victim and perpetrator. A similar programme is being trialled in 13 South Australian schools, where perpetrators and victims seek resolutions together. Learners take part in "circle time" to discuss concerns, and learners who have misbehaved are encouraged to make gifts to help rebuild relationships. Children who harass, assault, or are violent towards other children undergo mediation, apologise to classmates and sign a good-behaviour agreement (Youth Studies Australia, 2005b:4-5).

Even more important than programmatic solutions, is that the foundation for reducing bullying should be grounded in values "filled with life-view contents" (De Klerk \& Rens, 2003:368). Every school should consequently be transformed into a community that actively demonstrates, models and advocates in every way the spirit, courage, and commitment, according to Curwin (1995:74), to the "humane highway": all children are precious and needs to be respected, protected and valued. Educators must teach their learners the skills of nonviolent behaviour; but even more important, they must let them know that they are valued. To paraphrase the words of Yanosz Korczak (quoted in Curwin, 1995:75), who sacrificed his own life to comfort his learners as they were being sent from the Warsaw Ghetto to the death camp at Auschwitz: "Children are not to be valued for their potential. They are to be valued as humans in the here and now." 
The following educational values should not only be taught in schools, but cannot be separated from any effective anti-bullying programme:

- School is a place where people feel safe.

- School is a place where people learn.

- School is a place where prejudice, bigotry or sexism will not be tolerated.

- School is a place where each and every individual has value and worth.

- School is for all - learners, educators, administrators - not just for the best, the most well behaved, or the members of any one group.

\section{Concluding remarks}

The qualitative and quantitative data have revealed that not only verbal and physical, but also sexual bullying are pervasive and serious problems in some Free State schools. In the light of the seriousness of the long- and short-term effects of bullying for the bullies, the victims, the bystanders, educators, parents and the community at large, role players should strive to remove this evil from our schools. A comprehensive anti-bullying programme that includes all those involved, is required to ensure that learners can learn in a safe and bully-free environment. It should, however, be noted that even more important than programmatic solutions is the necessity for education to be grounded in sound legal, moral, religious and educational values. A prerequisite in the fight against bullying is an acknowledgement by adults and children alike, that bullying is not a normal part of growing up - it is dehumanising and degrading. The demand of the South African public to reduce violence in our schools will only be complied with if we listen to the voices of the victims of bullying - and act on it in a humane way.

\section{List of references}

ANON. 2005. "Last resort" school plagued by rumour. Saturday Star: 3, 9 Apr.

BALDRY, A.C. 2004. The impact of direct and indirect bullying on the mental and physical health of Italian youngsters. Aggressive Behavior, 30:343355.

BEAVER, T. 2005. Bullying should get the boot. Citizen: 9, 5 Apr.

BESAG, V. 1991. Parents and teachers working together. (In Elliot, M., ed. Bullying. Essex: Longman. p. 103-111.) 
BLAINE, S. 2005. Focus on crime in Cape schools. Business Day: 4, 18 Aug.

CIPANI, E. 2005. The Olweus bullying prevention program: a proven schoolbased program to reduce bullying. The Brown University Child and Adolescent Behaviour Letter, 21(4):1-5.

COLLINS, K., MCALEAVY, G. \& ADAMSON, G. 2004. Bullying in schools: a Northern Ireland study. Educational Research, 46(1):55-71.

CRAWTHON, R. 1999. Parents of bullies' victims fight back by suing schools. http://www.jaredstory.com/bull27.html Date of access: 10 Sept. 2005.

CURWIN, R.L. 1995. A humane approach to reducing violence in schools. Educational Leadership, 52(5):72-75.

DAKE, J.A., PRICE, J.H. \& TELLJOHANN, S.K. 2003. The nature and extent of bullying in school. Journal of School Health, 73(5):173-180.

DE KLERK, J. \& RENS, J. 2003. The role of values in school discipline. Koers, 68(4):353-371.

DE VRIES, A. 2002. Skoolboelies nog lank nie dood nie ... Burger: 9, 11 Okt.

DE WET, C. 2005. The nature and extent of bullying in Free State secondary schools. South African Journal of Education, 25(2):82-88.

DEPARTMENT OF HEALTH, 2002. The first South African youth risk behaviour survey. www.mrc.ac.za/healthpromotion/YSBSport5.pdf Date of access: 29 Aug. 2005.

DU TOIT, P. 2005. Tiener doodbang nadat skoolmaats hom lelik afknou. Beeld: 1, 29 Aug.

EDUCATION LAW NEWSLETTER. 2001. Tackling the bullies: schools' liability. http:/www.ruddwatts.com/newsroom/publications/education/june2001/educ ation.asp Date of access: 10 Sept. 2005.

ESLEA, M., MENESINI, E., MORITA, Y., O'MOORE, M., MORA-MENCHÁN, J.A., PEREIRA, B. \& SMITH, P.K. 2003. Friendship and loneliness among bullies and victims: data from seven countries. Aggressive Behavior, 30:71-83.

FOX, C.L. \& BOULTON, M.J. 2005. The social skills problems of victims of bullying: self, peer and teacher perceptions. British Journal of Educational Psychology, 75:313-328.

GLOVER, D., GOUGH, G., JOHNSON, M. \& CARTWRIGTH, N. 2000. Bullying in 25 secondary schools: incidence, impact and intervention. Educational Research, 42(2):141-156.

GUERIN, S. \& HENNESSY, E. 1999. Developing a pupil-based anti-bullying programme for schools. Poster presented at the British Psychcological Society Developmental Section Annual Conference, 6-9 September 1999. Nottingham: Department of Psychology, University of Nottingham.

KEITH, S. \& MARTIN, M.E. 2005. Cyber-bullying: creating a culture of respect in a cyber world. Reclaiming Children and Youth, 13(4):224-228.

MA, X., STEWIN, L.L. \& MAH, D.L. 2003. Bullying in schools: nature, effects and remedies. Research Papers in Education, 16(3):247-270.

MAKGALEMELE, T. 2005. R1m risk for ministry as parents sue. Saturday Star: $1,30 \mathrm{Jul}$.

NARAN, J. 2005. Reclaiming our lawless schools. Sunday Tribune: 4, 12 Jun.

NESER, J., OVENS, M., VAN DER MERWE, E., MORODI, R. \& LADIKOS, A. 2003. Bullying in schools: a general overview. Acta Criminologica, 16(1):127-157. 
OLWEUS, D. 2000a. Sweden. (In Smith, P.K., Morita, Y., Junger-Tas, J., Olweus, D., Catalano, R. \& Slee, P., eds. The nature of school bullying. London: Routledge. p. 7-27.)

OLWEUS, D. 2000b. Norway. (In Smith, P.K., Morita, Y., Junger-Tas, J., Olweus, D., Catalano, R. \& Slee, P., eds. The nature of school bullying. London: Routledge. p. 28-48.)

OLWEUS, D., LIMBER, S. \& MIHALIC, S.F. 1999. Blueprints for violence prevention. Book nine: Bullying prevention program. Boulder: Center for the Study and Prevention of Violence.

RIGBY, K. \& BAGSHAW, D. 2003. Prospects of adolescent students collaborating with teachers in addressing issues of bullying and conflict in schools. Educational Psychology, 23(5):535-546.

RODKIN, P.C. \& HODGES, E.V.E. 2003. Bullies and victims in the peer ecology: four questions for psychologists and school professionals. School Psychology Review, 32(2):384-400.

SELEKMAN, J. \& VESSEY, J.A. 2004. Bullying: it isn't what it used to be. Pediatric Nursing, 30(3):246-249.

SERRAO, A. \& RUSSOUW, S. 2005. Dad mourns needless death. Saturday Star: 3, 9 Apr.

SMIT, K. 2005. 3 slaan, steek mede-leerling glo by skool dood. Beeld: 5, 2 Jun.

SMOKOWSKI, P.R. \& KOPASZ, K.H. 2005. Bullying in schools: an overviews of types, effects, family characteristics and intervention strategies. Children \& Schools, 27(2):101-110.

SQUELCH, J.M. 2000. Discipline. Pretoria: CELP.

STATE OF DELAWARE. s.a. Delaware Bullying Questionnaire. (Consulted 2003-12-14.)

TREML, J.N. 2001. Bullying as a social malady in contemporary Japan. International Social Work, 44(1):107-117.

WHITTED, K.S. \& DUPPER, D.R. 2005. Best practices for preventing or reducing bullying in schools. Children \& Schools, 27(3):167-175.

WILL, J.D. \& NEUFELD, P.J. 2002. Taking appropriate action. Principal Leadership, 3(4):51-54.

YOUTH STUDIES AUSTRALIA. 2005a. Cyber Bullies, 24(2):5.

YOUTH STUDIES AUSTRALIA. 2005b. Anti-bullying Successes, 24(2):4-5.

\section{Key concepts:}

anti-bullying programmes

learner security

school bullying

\section{Kernbegrippe:}

anti-bullebakprogramme

bullebakkery in skole

leerderveiligheid 
